\title{
Microalgae biomass as an alternative ingredient in cookies: Sensory, physical and chemical properties, antioxidant activity and in vitro digestibility
}

\author{
Ana Paula Batista $^{\mathrm{a}, *}$, Alberto Niccolai ${ }^{\mathrm{b}}$, Patrícia Fradinho ${ }^{\mathrm{a}}$, Solange Fragoso ${ }^{\mathrm{a}}$, Ivana Bursic ${ }^{\mathrm{a}}$, \\ Liliana Rodolfi $^{\mathrm{b}, \mathrm{c}}$, Natascia Biondi ${ }^{\mathrm{b}}$, Mario R. Tredici ${ }^{\mathrm{b}}$, Isabel Sousa ${ }^{\mathrm{a}}$, Anabela Raymundo ${ }^{\mathrm{a}}$ \\ ${ }^{a}$ LEAF - Linking Landscape, Environment, Agriculture and Food, Instituto Superior de Agronomia, Universidade de Lisboa, Tapada da Ajuda, 1349-017 Lisboa, Portugal \\ b Department of Agrifood Production and Environmental Sciences (DISPAA), University of Florence, Piazzale delle Cascine 24, 50144 Florence, Italy \\ ${ }^{\mathrm{c}}$ Fotosintetica \& Microbiologica S.r.l., Via dei Della Robbia 54, 50132 Florence, Italy
}

\section{A R T I C L E I N F O}

\section{Keywords:}

Microalgae

Novel foods

Digestibility

Antioxidants

Phenolics

\begin{abstract}
A B S T R A C T
Microalgae can be regarded as an alternative and promising food ingredient due to their nutritional composition, richness in bioactive compounds, and because they are considered a sustainable protein source for the future. The aim of this work was to evaluate microalgae (Arthrospira platensis F \& M-C256, Chlorella vulgaris Allma, Tetraselmis suecica F \& M-M33 and Phaeodactylum tricornutum F \& M-M40) as innovative ingredients to enhance functional properties of cookies. Two biomass levels were tested and compared to control: $2 \%(\mathrm{w} / \mathrm{w})$ and $6 \%(\mathrm{w} /$ w), to provide high levels of algae-bioactives. The cookies sensory and physical properties were evaluated during eight weeks showing high color and texture stability. Cookies prepared with A. platensis and C. vulgaris presented significantly $(p<0.05$ ) higher protein content compared to the control, and by sensory analysis $A$. platensis cookies were preferred. Besides, A. platensis also provided a structuring effect in terms of cookies texture. All microalgae-based cookies showed significantly higher $(p<0.05)$ total phenolic content and in vitro antioxidant capacity compared to the control. No significant difference $(p<0.05)$ in in vitro digestibility between microalgae cookies and the control was found.
\end{abstract}

\section{Introduction}

Microalgae can be considered an innovative and promising food ingredient, rich in nutrients such as high value proteins, long-chain polyunsaturated fatty acids, carotenoids, vitamins, minerals, and phenolics as well as other bioactive molecules [1]. Different companies are currently investing in this innovative microalgae-based food sector, such as Terravia (ex-Solazyme, USA), currently producing and commercializing algae food ingredients such as protein isolates and culinary oils (http://terravia.com/). Another example is Dulcesol Group (http:// en.dulcesol.com/), leader in baked products and pastries sector in Spain, which has also invested in a microalgae production unit for developing a healthy baked product line with Chlorella incorporation [2-3]. Moreover, other companies are starting to pay attention to this area and according to Credence Research Report [4] the international algae products market is expected to reach US $\$ 44.7$ billion by 2023 , growing at a compound annual growth rate of $>5.0 \%$ in the 2016-2023 period. Nutraceuticals dominate the algae products market followed by Food \& Feed applications [4].
However, Europe lacks a gastronomy tradition and consumer history with microalgae (in contrast with some South-East Asia countries), which makes effective marketing and consumer acceptability of microalgae based products more difficult [5]. In fact, the use of microalgae as a food source is still poorly developed in Europe, which has been mainly attributed to three major factors: i) technical difficulties related to their cultivation and high production costs; ii) low demand in European countries compared to Asian markets; iii) strict European legislation regarding Novel Foods [5].

In the last years some works have been published on innovative and healthy food products integrated with microalgal biomass such as pasta, biscuits and vegetarian "mayonnaises" and gelled desserts [6-12]. Although the bioactive properties of microalgae biomass and/or of its extracts has been extensively demonstrated (e.g. $[1,13])$, only few studies deal with bioactivity of microalgae-based foods and their response to different processing steps $[10,14]$. There is a lack of knowledge on how food processing conditions influence digestibility, bioavailability and bioactive properties of microalgae functional ingredients in different food matrixes.

\footnotetext{
* Corresponding author.

E-mail address: paulabatista@isa.ulisboa.pt (A.P. Batista).
} 
Cookies are considered a convenient nutritious dense snack food, widely consumed by European citizens from all age groups. There is a tendency for research and innovation in this market segment, which promotes the inclusion in cookies of healthy ingredients, such as antioxidants, vitamins, minerals, proteins and fibers [15-16]. The inclusion of microalgae biomass in cookies has been previously reported for coloring purposes with Chlorella vulgaris [7], omega-3 fatty acids supplementation with Isochrysis galbana [8], and antioxidant activity with Spirulina [11-12].

The aim of this work was to study microalgae addition to enhance functional properties of this baked food matrix, especially at high biomass incorporation levels. It was intended to use significantly higher concentrations than the ones found in commercial algal products (typically below $1 \% \mathrm{w} / \mathrm{w}$ ), in order to provide higher levels of bioactive compounds, while not compromising sensorial acceptability and digestibility. Four microalgae strains were tested - Arthrospira platensis F \& M-C256, Chlorella vulgaris Allma, Tetraselmis suecica F \& M-M33, and Phaeodactylum tricornutum F \& M-M40.

A. platensis (commonly known as "spirulina"), consumed by human populations since ancient times [17] and C. vulgaris, C. luteoviridis and C. pyrenoidosa have been consumed in the EU for several decades and are thus authorized as food in the European Union [18-19]. A. platensis has been widely consumed as nutritional supplement due to its associated health benefits, such as high protein (up to $60 \%$ ), vitamin B12, $\gamma$ linolenic acid (GLA) and phycocyanin content [20]. Chlorella is also rich in protein, as well as pigments and glucans which can act as immunostimulants [21-22].

Tetraselmis chuii has recently been authorized for commercialization as novel food ingredient through an application by the company Fitoplancton Marino S.L. (Cadiz, Spain) [23]. In the present study, another species belonging to the same genus, T. suecica, was used. This marine chlorophyte is characterized by high content in polyunsaturated fatty acids and $\alpha$-tocopherol [24].

$P$. tricornutum is a marine diatom which has not yet been submitted to novel food application. Nevertheless, it was included in the present study considering its high content in eicosapentaenoic acid (EPA 20:5 $\omega 3$ ) as well as in fucoxanthin, a carotenoid associated with antioxidant, anti-diabetes and anti-obesity effects [25-26]. Moreover, previous in vitro toxicity tests by Niccolai et al. [27] showed no adverse effects of methanolic and aqueous extracts of these biomasses on Artemia salina.

\section{Materials and methods}

\subsection{Microalgae strains and biomass production}

Arthrospira platensis F \& M-C256 and Tetraselmis suecica F \& M-M33 biomasses were provided by Archimede Ricerche S.r.l. (Camporosso, Imperia, Italy) and Phaeodactylum tricornutum F \& M-M40 was produced at the facility of Fotosintetica \& Microbiologica S.r.l. (Sesto Fiorentino, Florence, Italy). A. platensis F \& M-C256, T. suecica F \& M-M33, and $P$. tricornutum F \& M-M40 were cultivated in GWP ${ }_{-1}^{-I}$ [28] or GWP ${ }^{\circledR}$-II photobioreactors [29-30] in semi-batch mode, then the biomasses were harvested by centrifugation, frozen, lyophilized, powdered and stored at $-20{ }^{\circ} \mathrm{C}$ until analysis. A. platensis F \& M-C256 biomass was washed with tap water to remove excess bicarbonate before being frozen. Chlorella vulgaris Allma biomass was obtained from Allma Microalgae (Lisbon, Portugal). The two marine strains (T. suecica F \& M-M33 and $P$. tricornutum F \& M-M40) were cultivated in F medium [31], while $A$. platensis F \& M-C256 was cultivated in Zarrouk medium [32]. The biochemical composition of the different biomasses, determined as reported in Abiusi et al. [33], is presented in Table 1.

\subsection{Cookies preparation}

Cookies were prepared according to a previously optimized formulation [7-8], using wheat flour, sugar, baking powder, margarine,
Table 1

Biochemical composition of the four microalgae biomasses used in the experiments (\%, dry weight). Results are expressed as average \pm standard deviation $(n=3)$.

\begin{tabular}{lllll}
\hline & Protein (\%) & Carbohydrate (\%) & Lipid (\%) & Ash (\%) \\
\hline $\begin{array}{c}\text { A. platensis F \& M- } \\
\text { C256 }\end{array}$ & $68.9 \pm 1.0$ & $12.8 \pm 0.2$ & $10.7 \pm 0.6$ & $6.1 \pm 0.1$ \\
$\begin{array}{l}\text { C. vulgaris Allma } \\
\text { T. suecica F \& M- } \\
\quad \text { M33 }\end{array}$ & $56.8 \pm 2.7$ & $5.9 \pm 0.3$ & $16.9 \pm 2.8$ & $9.3 \pm 1.5$ \\
$\begin{array}{c}\text { P. tricornutum } \\
\text { F \& M-M40 }\end{array}$ & $38.8 \pm 0.1$ & $10.2 \pm 0.2$ & $28.5 \pm 1.2$ & $15.7 \pm 0.2$ \\
& & & $19.3 \pm 0.7$ & $1.7 \pm 0.1$ \\
\hline
\end{tabular}

Table 2

Cookie formulations (\%,w/w). F1 - control cookie formulation; F2 - 2\% algae cookie formulation; F3 - 6\% algae cookie formulation.

\begin{tabular}{llll}
\hline Ingredients & F1 (control) & $\mathrm{F} 2$ & $\mathrm{~F} 3$ \\
\cline { 2 - 4 } & $\mathrm{g} / 100 \mathrm{~g}$ & $\mathrm{~g} / 100 \mathrm{~g}$ & $\mathrm{~g} / 100 \mathrm{~g}$ \\
\hline Wheat flour & 49 & 47 & 43 \\
Sugar & 20 & 20 & 20 \\
Margarine & 20 & 20 & 20 \\
Water & 10 & 10 & 10 \\
Baking powder & 1 & 1 & 1 \\
Microalgae & 0 & 2 & 6 \\
\hline
\end{tabular}

and microalgae biomass, as indicated in Table 2. A control, without microalgae incorporation was also prepared and further analyzed. Batches of $150 \mathrm{~g}$ were prepared, yielding around 10 cookies per batch. The ingredients were mixed in a food processor (Bimby, Vorwerk), kneading $15 \mathrm{~s}$ at speed 4 . The cookies were then molded into $46.5 \mathrm{~mm}$ diameter and $5 \mathrm{~mm}$ height circles disks and baked at $110{ }^{\circ} \mathrm{C}$ for $40 \mathrm{~min}$. After cooling, sample cookies were stored at room temperature in hermetic containers, protected from light. Physical analyses (color, texture, and $\mathrm{a}_{\mathrm{w}}$ ) were performed after $24 \mathrm{~h}$, and after 8 weeks storage. Some of the cookies batches were immediately crushed to powder (using an electric mill) and frozen to be used for chemical composition, antioxidant capacity and in vitro digestibility analyses.

\subsection{Cookies analyses}

\subsubsection{Color analysis}

The color of cookies samples was measured instrumentally using a Minolta CR-400 (Japan) colorimeter with standard illuminant D65 and a visual angle of $2^{\circ}$. The results were expressed in terms of $L^{*}$, lightness (values increase from 0 to $100 \%$ ); $\mathrm{a}^{*}$, redness to greenness (60 to -60 positive to negative values, respectively); $b^{*}$, yellowness to blueness (60 to -60 positive to negative values, respectively), according to the CIELab system. Chroma, $\mathrm{C}^{*}$ ab (saturation), and hue angle, $\mathrm{h}_{\mathrm{ab}}^{\circ}$, were also calculated, as defined by: $\mathrm{C}^{*}{ }_{\mathrm{ab}}=\left[\left(\mathrm{a}^{* 2}+\mathrm{b}^{* 2}\right)\right]^{1 / 2} ; \mathrm{h}_{\mathrm{ab}}^{\circ}=\arctan$ $\left(b^{*} / a^{*}\right)$. The total color difference between sample cookies along storage time (up to eight weeks), as well as between raw and cooked samples, was determined using average $\mathrm{L}^{*} \mathrm{a} * \mathrm{~b} *$ values according to: $\Delta \mathrm{E}^{*}=\left[\left(\Delta \mathrm{L}^{*}\right)^{2}+\left(\Delta \mathrm{a}^{*}\right)^{2}+\left(\Delta \mathrm{b}^{*}\right)^{2}\right]^{1 / 2}$. The measurements were conducted under the same light conditions, using a white standard $\left(L^{*}=94.61, a^{*}=-0.53, b^{*}=3.62\right)$, under artificial fluorescent light at room temperature, replicated ten times for each formulation sample (one measurement per cookie), as well as for the control, $24 \mathrm{~h}$ and 8 weeks after preparation.

\subsubsection{Texture analysis}

The cookie texture was measured using a texturometer TA.XTplus (Stable MicroSystems, UK) in penetration mode with a cylindrical aluminum probe of $2 \mathrm{~mm}$ diameter plunged $3 \mathrm{~mm}$ at $1 \mathrm{~mm} \mathrm{~s}^{-1}$. The resistance to penetration, or hardness, was measured by the total area below the force $v s$. time curve, corresponding to the penetration work 
(N.s). Measurements were repeated ten times for each formulation sample (one measurement per cookie), as well as for the control, $24 \mathrm{~h}$ and 8 weeks after preparation.

\subsubsection{Water activity $\left(a_{w}\right)$ determination}

The cookie water activity $\left(\mathrm{a}_{\mathrm{w}}\right)$ was determined using an HygroPalm HP23-AW (Rotronic AG, Switzerland), at $20 \pm 1{ }^{\circ} \mathrm{C}$. Measurements were repeated four times for each sample (crushed powder), as well as for the control, $24 \mathrm{~h}$ and 8 weeks after preparation.

\subsubsection{Proximate chemical composition determination}

Cookie moisture content was determined gravimetrically using an automatic moisture analyzer PMB 202 (aeADAM, Milton Keynes, UK) at $130^{\circ} \mathrm{C}$, until constant weight.

Total ash content was determined gravimetrically by incineration at $550{ }^{\circ} \mathrm{C}$ in a muffle furnace.

Crude protein was determined by the Kjeldhal method according to the AOAC 950.36 official method for baked products [34]. The determined total nitrogen content was multiplied by a conversion factor of 5.7 to obtain the cookie crude protein content.

The cookie crude fat content was determined according to the procedure used for cereals and derived products in the Portuguese standard method NP4168 [35]. This procedure is based on the hydrolysis of the bonds between lipids, proteins, and carbohydrates by using hydrochloric acid, ethanol and formic acid, followed by filtration and extraction with $n$-hexane in a Soxhlet extractor for $6 \mathrm{~h}$. The crude fat residue was determined gravimetrically, after solvent evaporation in a rotary evaporator and oven drying.

All chemical composition analyses were repeated, at least in triplicate, and were performed after cookie preparation.

\subsubsection{Phycocyanin, phenolics and antioxidant capacity determination}

Phycocyanin content was determined in A. platensis cookie, and respective dough samples, according to the method developed by Boussiba \& Richmond [36] modified by Reis et al. [37]. This method is based on the extraction of these water soluble pigments with phosphate buffer at $\mathrm{pH} 7,0.1 \mathrm{M}$ at low temperatures and spectrophotometric quantification at $620 \mathrm{~nm}$ (C-phycocyanin) and $650 \mathrm{~nm}$ (C-allophycocyanin).

For total phenolic content determination, extracts were prepared according to the procedure used by Hajimahmoodi et al. [38]. The total phenolic content in the extracts was determined according to Rajauria et al. [39], using the Folin Ciocalteu assay. Results were expressed in gallic acid equivalents ( $\mathrm{mg} \mathrm{GAE}^{-1}$ ) of dry microalgae biomass and cookies, through a calibration curve with gallic acid (0 to $500 \mu \mathrm{g} \mathrm{mL}^{-1}$ ).

The antioxidant capacity of the cookies and microalgae samples was assessed by direct quencher procedure, as optimized by Serpen et al. [40-41] for cereal products, using Ferric Reducing Antioxidant Power (FRAP) as quantification method. Two blank assays, one without sample and another without reagents were also performed. Standard calibration curves were made using Trolox standard solutions that were submitted to the same FRAP protocol. The antioxidant capacity of the samples was expressed in terms of mmol of Trolox Equivalent Antioxidant Capacity (TEAC) per kilogram of sample. Analyses were repeated in triplicate and performed after cookie preparation.

\subsubsection{In vitro digestibility tests}

The cookies and microalgae biomasses in vitro digestibility (IVD) was assessed by the Boisen \& Fernández method [42]. Microalgae biomass and cookie samples were weighed $(1 \mathrm{~g}$, particle size $\leq 1 \mathrm{~mm})$ and transferred in $250 \mathrm{~mL}$ conical flasks. To each flask, phosphate buffer ( $25 \mathrm{~mL}, 0.1 \mathrm{M}, \mathrm{pH} 6.0)$ was added and mixed, followed by $\mathrm{HCl}(10 \mathrm{~mL}$, $0.2 \mathrm{M}$ ) and $\mathrm{pH}$ was adjusted to 2.0. A freshly prepared pepsin water solution ( $3 \mathrm{~mL}$; Applichem, Darmstadt, Germany) containing $30 \mathrm{mg}$ of porcine pepsin ( $0.8 \mathrm{FIP}-\mathrm{U} / \mathrm{mg}$ ) was added. The flasks were incubated at $39^{\circ} \mathrm{C}$ for $6 \mathrm{~h}$ with constant agitation (150 rpm). After, phosphate buffer (10 mL, $0.2 \mathrm{M}, \mathrm{pH} 6.8$ ) and $\mathrm{NaOH}$ solution $(5 \mathrm{~mL}, 0.6 \mathrm{M}$ ) were added to each sample and $\mathrm{pH}$ was adjusted to 6.8. A freshly prepared pancreatin ethanol:water solution $(10 \mathrm{~mL}, 50: 50 \mathrm{v} / \mathrm{v})$ containing $500 \mathrm{mg}$ of porcine pancreatin (42362 FIP-U/g, Applichem, Darmstadt, Germany) was added to each sample. The flasks were incubated again at $39^{\circ} \mathrm{C}$, $150 \mathrm{rpm}$, for $18 \mathrm{~h}$. A reagent blank without sample was also prepared. The undigested residues were collected by centrifugation at 18,000 $\times g$ for $30 \mathrm{~min}$ and washed with deionised water. This procedure was repeated twice and the final supernatant was filtered on glass-fiber membranes ( $47 \mathrm{~mm} \emptyset$, pore $1.2 \mu \mathrm{m}$ ). The pellet and membranes were dried at $80{ }^{\circ} \mathrm{C}$ for $6 \mathrm{~h}$, and then at $45{ }^{\circ} \mathrm{C}$ until constant weight.

The IVD (\%) was calculated from the difference between the initial biomass and the undigested biomass (after correction for the blank assay) divided by the initial biomass and multiplied by 100 . Analyses were repeated in triplicate.

\subsubsection{Sensory analysis}

Sensory analysis assays were performed for cookies with $C$. vulgaris and A. platensis ( $2 \%$ and $6 \%$ ). An untrained panel of 41 people, 9 males and 32 females, with ages between 18 and 60, evaluated the cookies in terms of color, smell, taste, texture, global appreciation (6 levels from "very pleasant" to "very unpleasant"). The buying intention was also assessed, from "would certainly buy" to "certainly wouldn't buy" (5 levels). The assays were conducted in a standardized sensory analysis room, according to the standard EN ISO 8589 [43].

\subsection{Statistical analysis}

Statistical analysis of the experimental data was performed using STATISTICA from StatSoft (version 8.0), through variance analysis (one way ANOVA), by the Scheffé test - Post Hoc Comparison at a significance level of $95 \%(p<0.05)$. All results are presented as average \pm standard deviation.

\section{Results and discussion}

The cookies with microalgae biomass incorporation presented visually attractive and unusual appearances (Fig. 1). Innovative green tonalities varied, depending on the microalga used, from a blueishgreen (A. platensis) to a brownish-green ( $P$. tricornutum). The microalgae cookies presented an average diameter of $46.8 \pm 0.5 \mathrm{~mm}$ and an average thickness of $7.5 \pm 0.3 \mathrm{~mm}$ while the control cookie dimensions were slightly higher $(47.9 \pm 1.5 \mathrm{~mm}$ diameter, $8.3 \pm 0.5 \mathrm{~mm}$ thickness).

\subsection{Color stability}

The results obtained for the cookie color parameters, lightness $\left(\mathrm{L}^{*}\right)$, greenness $\left(\mathrm{a}^{*}\right)$, yellowness $\left(\mathrm{b}^{*}\right)$, chroma $\left(\mathrm{C}^{*}\right)$ and hue $\left(\mathrm{h}^{\circ}\right)$ are presented in Fig. 2. Regarding the lightness parameter $\mathrm{L}^{*}$, a reduction in luminosity with increasing algae concentration can be observed.

An increase in microalgae concentration has also led to lower values of the chromatic parameters $\mathrm{a}^{*}$ and $\mathrm{b}$ * (in modulus), thus lower chroma $\left(C^{*}\right)$, while the hue remains practically constant for each sample $\left(100^{\circ}\right.$ to $120^{\circ}$, between yellow and green, depending on the sample).

These results may seem unexpected, considering that in Fig. 1, the cookies with $6 \%$ algae seem to have more intense green color. In previous studies, a similar effect was found for C. vulgaris [7] and Isochrysis galbana [8] cookies, where a reduction in $\mathrm{a}^{*}$ and $\mathrm{b}^{*}$ parameters upon increasing microalgae biomass concentration from $0.5 \%$ to $3.0 \%(\mathrm{w} / \mathrm{w})$ was observed. This effect may be related to a higher pigment degradation with the baking process or with a pigment saturation effect, above certain algae concentrations.

Cookies with $2 \%$ C. vulgaris and T. suecica presented the highest a* values (in modulus) and intermediate $b^{*}$ values (22.8-25.3) (Fig. 2), 


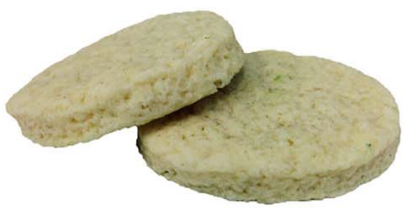

Control

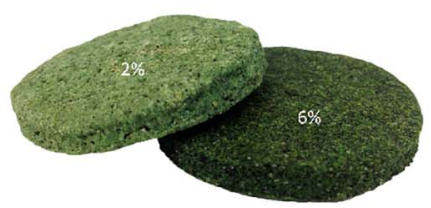

A. platensis

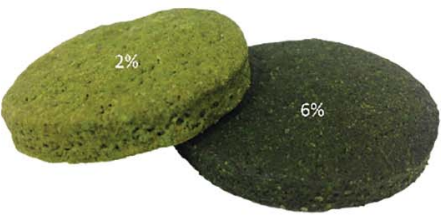

T. suecica

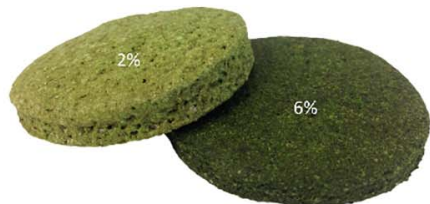

C. vulgaris

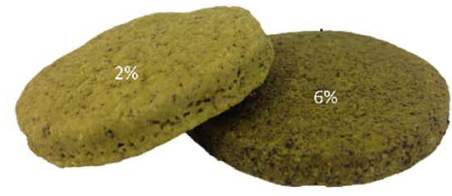

P. tricornutum

Fig. 1. Control cookie and cookies with $2 \%(\mathrm{w} / \mathrm{w})$ and $6 \%(\mathrm{w} / \mathrm{w})$ microalgae biomass.

which is in agreement with the high chlorophyll content that characterizes chlorophyte algae [1]. A. platensis cookies presented tonalities similar to the chlorophyte cookies, although with less intensity (lower $\mathrm{a}^{*}$ and $\mathrm{b}^{*}$ values, in modulus), reflecting the lower chlorophyll and carotenoid content generally present in this alga [44]. On the other hand, $P$. tricornutum cookies presented low a* values (in modulus) and the highest $b^{*}$ values, resulting in a hue angle of $100^{\circ}$, closer to yellow $\left(90^{\circ}\right)$ than to green $\left(180^{\circ}\right)$. These results should be related to the
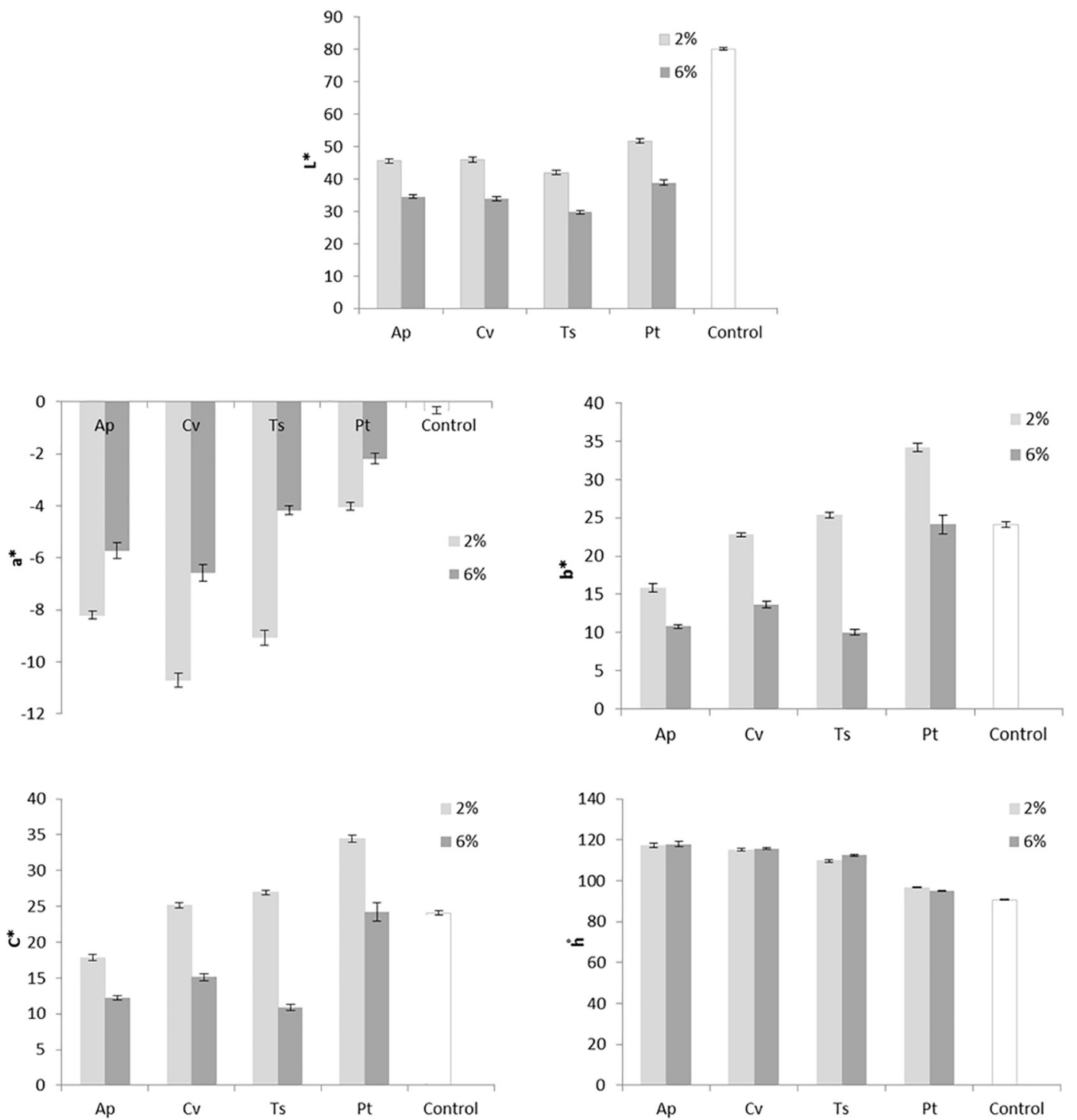

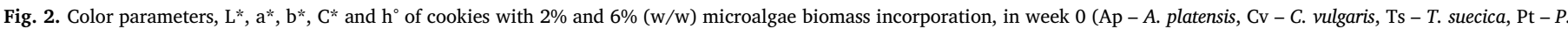
tricornutum). Results are expressed as average \pm standard deviation $(\mathrm{n}=10)$. 
Table 3

Total color variation $\left(\Delta \mathrm{E}^{*}\right)$ between cooked and raw cookie samples and color stability along conservation time $\left(\Delta \mathrm{E}^{*}\right.$ in relation to week 0$)$.

\begin{tabular}{llllllll}
\hline $\begin{array}{l}\text { Total color difference } \\
\left(\Delta \mathrm{E}^{*}\right)\end{array}$ & $\begin{array}{l}\text { Raw vs. } \\
\text { cooked }\end{array}$ & $\begin{array}{l}\text { Week 1 } \\
\text { vs. } \\
\text { week 0 }\end{array}$ & $\begin{array}{l}\text { Week 2 } \\
\text { vs. } \\
\text { week 0 }\end{array}$ & $\begin{array}{l}\text { Week 3 } \\
\text { vs. } \\
\text { week 0 }\end{array}$ & $\begin{array}{l}\text { Week } 4 \\
\text { vs. } \\
\text { week 0 }\end{array}$ & $\begin{array}{l}\text { Week 8 } \\
\text { vs. } \\
\text { week 0 }\end{array}$ \\
\hline Control & & 7.63 & 0.84 & 0.86 & 1.23 & 1.55 & 1.89 \\
A. platensis & $2 \%$ & 16.01 & 0.60 & 0.66 & 1.16 & 1.63 & 1.86 \\
& $6 \%$ & 15.58 & 0.73 & 0.89 & 0.94 & 0.94 & 0.77 \\
C. vulgaris & $2 \%$ & 11.22 & 0.70 & 1.17 & 0.96 & 0.74 & 1.12 \\
& $6 \%$ & 12.58 & 0.75 & 1.26 & 1.11 & 1.32 & 3.13 \\
T. suecica & $2 \%$ & 15.93 & 1.02 & 1.73 & 2.43 & 2.49 & 2.78 \\
& $6 \%$ & 10.85 & 1.83 & 2.12 & 2.40 & 3.80 & 4.69 \\
P. tricornutum & $2 \%$ & 18.97 & 1.50 & 2.03 & 2.48 & 2.37 & 4.19 \\
& $6 \%$ & 23.63 & 1.31 & 2.57 & 2.37 & 3.35 & 5.42 \\
\hline
\end{tabular}

presence of fucoxanthin, a carotenoid usually present in high concentrations in this marine diatom [25].

Table 3 presents the total color differences $\left(\Delta \mathrm{E}^{*}\right)$ between baked and raw (dough) sample cookies. Microalgae cookies show significantly color differences upon baking $\left(\Delta \mathrm{E}^{*}=19-24\right)$. These differences result mainly from a general increase in luminosity (probably associated to water evaporation) and an accentuated hue angle tonality decrease in the case of $P$. tricornutum (results not shown), which should be related to pigment loss upon baking.

The color stability along conservation time can also be observed in Table 3 through the calculation of total color difference of each sample with time in relation to week 0 . In all cases $\Delta \mathrm{E}^{*}$ is lower than 5 (except for $P$. tricornutum $6 \%$ in week 8: 5.42) which means that the cookie color differences are not detected by normal human vision [45]. Therefore, it can be concluded that the developed cookies present stable colorations along eight weeks of storage.

\subsection{Texture stability}

The cookies texture was evaluated by penetration tests, and the resulting hardness, expressed by resistance to penetration work, was calculated from the texturograms and presented in Fig. 3.

At the beginning of the study (week 0), no significant differences $(p>0.05)$ were found between the cookies with $2 \%$ algae when compared to the control (and between different algae), which means that adding $2 \%$ biomass does not prompt cookie structural changes that can alter the resistance to probe penetration. Increasing microalgae concentration from $2 \%$ to $6 \%$ causes significant $(p<0.05)$ hardness increase, from 24 to 29 N.s ( $2 \%$ cookies) to $37-38$ N.s for $6 \%$ C. vulgaris and T. suecica cookies, to 50 N.s for P. tricornutum and to 63 N.s for A. platensis cookies.
These results confirm the findings of previous water absorption tests carried out with the same microalgae strains biomass [46], in which significantly higher $(p<0.05)$ water absorption indexes (WAI: 4.4-5.0 g/galga) and Oil Absorption Capacity (OAC: $1.8-2.2 \mathrm{~g} / \mathrm{g}_{\text {alga }}$ ) were obtained in relation to wheat flour (WAI: $2.1 \mathrm{~g} / \mathrm{g}_{\text {flour }}$, OAC: $1.7 \mathrm{~g} /$ $\left.\mathrm{g}_{\text {flour }}\right)$. The highest WAI and OAC values were attained for A. platensis, followed by P. tricornutum, and at last, for C. vulgaris and T. suecica, which can be related to the different nature of these algae cell walls (peptidoglycan, silica and cellulose/hemicellulose, respectively). It is possible that, when microalgae are added to the cookie dough, they absorb more water and oil/fat, reinforcing the cookie internal structure. These data suggest that it would be possible to increase the water content or reduce the flour content, resulting in cookies with the same texture properties than the control cookie.

These results are also in agreement with previous studies where it was observed a linear increase in cookies hardness with C. vulgaris [7] and I. galbana [8] at concentrations from $0.5 \%$ to $3.0 \%$. Singh et al. [12] also observed that increasing the content of A. platensis, from 1.6 to $8.4 \%$, had positive effect on the hardness of sorghum flour biscuits. The same "texturing" or "structuring" effect of microalgae has been described also in other type of food products, such as fresh pastas with A. maxima and C. vulgaris [9].

The evolution of cookies hardness with time can also be observed in Fig. 3. The cookies did not present significant $(p>0.05)$ changes in hardness after eight weeks of storage, except for A. platensis cookies.

\subsection{Water activity}

Water activity, $\mathrm{a}_{\mathrm{w}}$, is an important physical parameter regarding conservation of low moisture cookies, particularly for the maintenance of a crispy texture [47]. At $\mathrm{a}_{\mathrm{w}}$ values below 0.5 , no microbial proliferation occurs. Lipid oxidation reactions, can be accelerated at high $\mathrm{a}_{\mathrm{w}}$ by increased mobilization of reactant molecules, although it is also recognized that very low water contents in fat-containing foods (e.g. cookies with $3-5 \%$ moisture and $20 \%$ fat) are conductive to rapid oxidation since substrates and reactants become more concentrated [48].

Fig. 4 presents the results of $a_{w}$ for the microalgae cookies along eight weeks. The control cookies presented an average $\mathrm{a}_{\mathrm{w}}$ value of 0.29 without significant differences with time $(p<0.05)$. Microalgae cookies presented more variable behavior regarding $a_{w}$ values, with a tendency for $\mathrm{a}_{\mathrm{w}}$ to increase along time. Overall, it should be noted that for all samples, $a_{w}$ values were below 0.5, after eight weeks storage, these $a_{w}$ variations did not promote any appreciable modification on texture stability (Fig. 3).

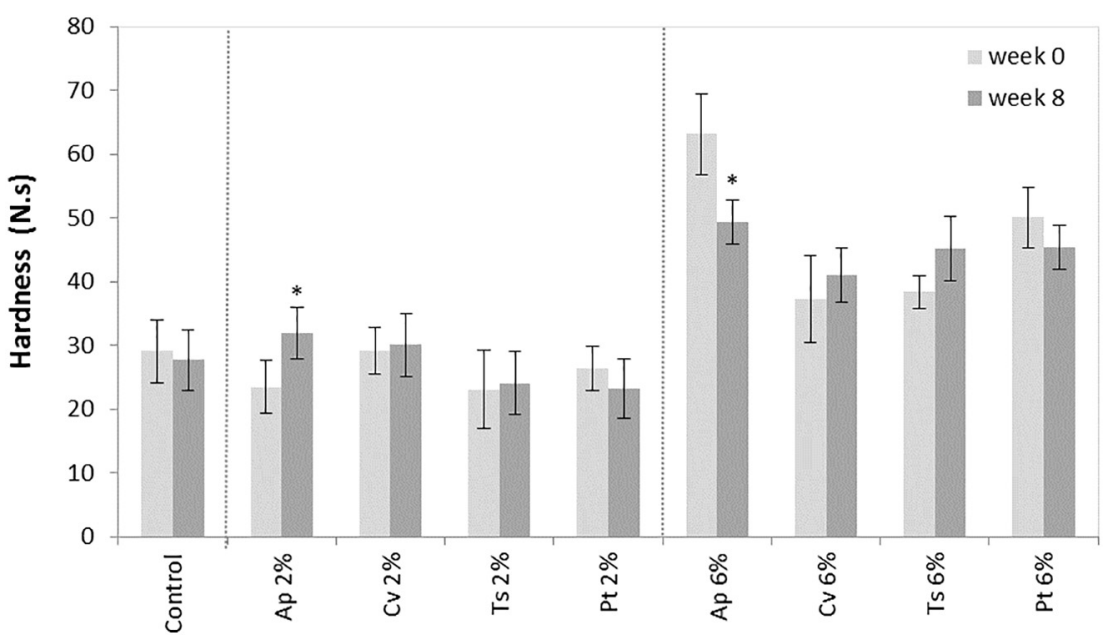

Fig. 3. Texture, expressed by penetration work (hardness, area N.s), of cookies with $2 \%$ and $6 \%(\mathrm{w} / \mathrm{w})$ microalgae biomass incorporation, along time (Ap - A. platensis, $\mathrm{Cv}-$ C. vulgaris, Ts - T. suecica, $\mathrm{Pt}-$ $P$. tricornutum). Results are expressed as average \pm standard deviation $(\mathrm{n}=10)$. Samples marked with * showed significant $(p<0.05)$ differences from week 0 to week 8 . 


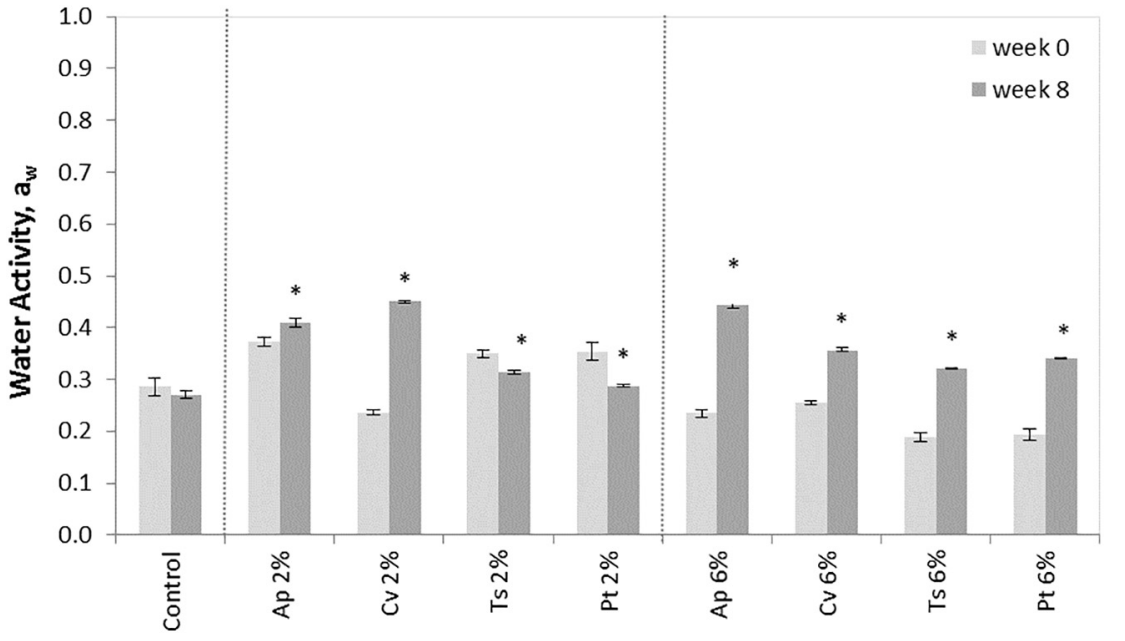

Fig. 4. Evolution of water activity $\left(a_{w}\right)$, of cookies with $2 \%$ and $6 \%$ (w/w) microalgae biomass incorporation, along time (Ap - A. platensis, $\mathrm{Cv}-\mathrm{C}$. vulgaris, Ts - T. suecica, $\mathrm{Pt}-\mathrm{P}$. tricornutum). Results are expressed as average \pm standard deviation $(n=4)$. Samples marked with * showed significant $(p<0.05)$ differences from week 0 to week 8 .

Table 4

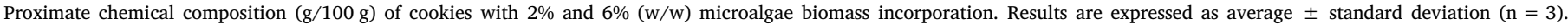
Different letters in the same column correspond to significant differences $(p<0.05)$.

\begin{tabular}{|c|c|c|c|c|c|c|c|}
\hline & & $\begin{array}{l}\text { Moisture } \\
(\mathrm{g} / 100 \mathrm{~g})\end{array}$ & $\begin{array}{l}\text { Total ash } \\
(\mathrm{g} / 100 \mathrm{~g})\end{array}$ & $\begin{array}{l}\text { Crude fat } \\
(\mathrm{g} / 100 \mathrm{~g})\end{array}$ & $\begin{array}{l}\text { Crude protein } \\
(\mathrm{g} / 100 \mathrm{~g})\end{array}$ & $\begin{array}{l}\text { Carbohydrates* } \\
(\mathrm{g} / 100 \mathrm{~g})\end{array}$ & $\begin{array}{l}\text { Energy value } \\
\text { (kcal/100 g) }\end{array}$ \\
\hline Control & & $3.8 \pm 0.2^{\mathrm{ab}}$ & $2.7 \pm 0.2^{\mathrm{a}}$ & $16.1 \pm 0.1^{\mathrm{a}}$ & $4.9 \pm 0.5^{\mathrm{a}}$ & 72.6 & 454 \\
\hline \multirow[t]{2}{*}{ A. platensis } & $2 \%$ & $3.8 \pm 0.1^{\mathrm{ab}}$ & $2.6 \pm 0.4^{\mathrm{a}}$ & $16.1 \pm 0.5^{\mathrm{a}}$ & $6.1 \pm 0.2^{\mathrm{abc}}$ & 71.4 & 455 \\
\hline & $6 \%$ & $5.0 \pm 0.2^{\mathrm{d}}$ & $2.3 \pm 0.1^{\mathrm{a}}$ & $16.1 \pm 0.1^{\mathrm{a}}$ & $7.8 \pm 0.3^{\mathrm{de}}$ & 68.7 & 451 \\
\hline \multirow[t]{2}{*}{ C. vulgaris } & $2 \%$ & $3.2 \pm 0.1^{\mathrm{a}}$ & $2.3 \pm 0.1^{\mathrm{a}}$ & $16.3 \pm 0.2^{\mathrm{a}}$ & $5.9 \pm 0.5^{\mathrm{abc}}$ & 72.4 & 460 \\
\hline & $6 \%$ & $4.8 \pm 0.3^{\mathrm{cd}}$ & $2.6 \pm 0.1^{\mathrm{a}}$ & $16.9 \pm 0.4^{\mathrm{a}}$ & $8.0 \pm 0.6^{\mathrm{e}}$ & 67.7 & 455 \\
\hline \multirow[t]{2}{*}{ T. suecica } & $2 \%$ & $3.4 \pm 0.2^{\mathrm{ab}}$ & $2.4 \pm 0.2^{\mathrm{a}}$ & $16.1 \pm 0.1^{\mathrm{a}}$ & $5.2 \pm 0.1^{\mathrm{a}}$ & 73.0 & 457 \\
\hline & $6 \%$ & $3.3 \pm 0.1^{\mathrm{a}}$ & $3.2 \pm 0.1^{\mathrm{a}}$ & $16.3 \pm 0.4^{\mathrm{a}}$ & $6.9 \pm 0.4^{\mathrm{cd}}$ & 70.4 & 456 \\
\hline \multirow[t]{2}{*}{ P. tricornutum } & $2 \%$ & $3.9 \pm 0.1^{\mathrm{ab}}$ & $2.3 \pm 0.2^{\mathrm{a}}$ & $16.1 \pm 0.1^{\mathrm{a}}$ & $5.1 \pm 0.2^{\mathrm{ab}}$ & 72.6 & 456 \\
\hline & $6 \%$ & $4.3 \pm 0.2^{\mathrm{bc}}$ & $3.0 \pm 0.1^{\mathrm{a}}$ & $16.2 \pm 0.1^{\mathrm{a}}$ & $6.6 \pm 0.4^{\mathrm{bc}}$ & 70.0 & 452 \\
\hline
\end{tabular}

* Carbohydrates were calculated by difference.

\subsection{Proximate chemical composition}

Table 4 presents the proximate chemical composition of the cookies prepared with microalgae biomass incorporation.

All cookies presented moisture values ranging from 3.2 to $5.0 \%$, which is typical for this type of dried foods. No significant changes $(p<0.05)$ were observed on the cookies ash content upon microalgae addition (2.3-3.2\%) neither on the crude fat content (16.1-16.9\%).

The main chemical composition changes arising from microalgae incorporation in cookies are related to protein (Table 4). The protein content of microalgae cookies was always higher than the control cookie (4.9\%). Cookies with $2 \%$ algae ranged from 5.1 to $6.1 \%$ protein while $6 \%$ algae cookies ranged from 6.6 to $8.0 \%$ protein. The highest values were attained for $A$. platensis and $C$. vulgaris cookies with protein contents around $8 \%$. Bolanho et al. [49] found an increase of $20 \%$ in protein content of samples with $5 \%$ A. platensis biomass added, when compared to the control cookie, which is similar to the increase found in our study for the cookies with $2 \%$ A. platensis biomass $(+24 \%)$. Furthermore, when we increased A. platensis content up to $6 \%$, a $+59 \%$ increase in protein content was obtained compared to the control cookie.

\subsection{Bioactive compounds and antioxidant capacity}

The presence of bioactive compounds in the microalgae biomass could be associated to antioxidant potential, among other biological functions.

In the case of $A$. platensis cookies, it should be noted the presence of phycocyanin, a blue pigment with demonstrated nutraceutical properties and healthy benefits which are mainly attributed to its antioxidant activity [50]. Even after thermal treatment, the cookies presented
$172 \mathrm{mg} \mathrm{kg}^{-1}$ and $363 \mathrm{mg} \mathrm{kg}^{-1}$ phycocyanin for $2 \%$ and $6 \%$ incorporation levels (data not shown), respectively, thus about $10 \%$ of phycocyanin from the microalga biomass $(8.2 \% \mathrm{w} / \mathrm{w})$ was still present. In previous studies [51], this pigment has been used as coloring and functional ingredient in oil-in-water food emulsions, proving also to be a powerful structuring agent.

Phenolic compounds including simple phenols, flavonoids, phenylpropanoids, tannins, lignins, phenolic acids, and their derivatives, synthesized as secondary metabolites [52] are considered as one of the most important classes of natural antioxidants and have received an increasing interest from consumers and also from food manufacturers for their health benefits [53]. Fig. 5 shows the phenolic content of microalgae cookies and microalgae biomass. A. platensis biomass presented the highest $(p<0.05)$ total phenolic content $\left(19 \mathrm{mg} \mathrm{GAE} \mathrm{g}^{-1}\right)$, followed by $T$. suecica $\left(9.2 \mathrm{mg} \mathrm{GAE}^{-1}\right), P$. tricornutum $(8.4 \mathrm{mg} \mathrm{G}$ $\mathrm{AE}^{-1}$ ) and C. vulgaris (6.4 $\mathrm{mg} \mathrm{GAE}^{-1}$ ) (Fig. 5A).

The addition of microalgae results in an effective supplementation of phenolic compounds, which are practically absent in the control cookie. A. platensis $6 \%$ cookies presented the highest phenolic content ( $0.90 \mathrm{mg} \mathrm{GAE}^{-1}$ ), which is in agreement with this alga composition, followed by $P$. tricornutum $6 \%$ cookies $\left(0.62 \mathrm{mg} \mathrm{GAE} \mathrm{g}^{-1}\right)$. Both $A$. platensis and $P$. tricornutum $2 \%$ cookies also showed much higher phenolic content than the chlorophyte algae at the highest concentration (C. vulgaris and T. suecica). When submitted to baking $\left(110^{\circ} \mathrm{C} / 40 \mathrm{~min}\right)$ Chlorophyceae algae showed high phenolic losses, in the order of $50 \%$ for C. vulgaris and $80 \%$ for T. suecica. On the other hand, P. tricornutum cookies showed high final phenolic content, without appreciable losses in relation to the microalgal biomass, upon baking. It is possible that the different cell wall of $P$. tricornutum, (presenting silica bands or an amorphous silica matrix according to the morphotype) [54], when compared to the other microalgae, had a higher protecting effect for 

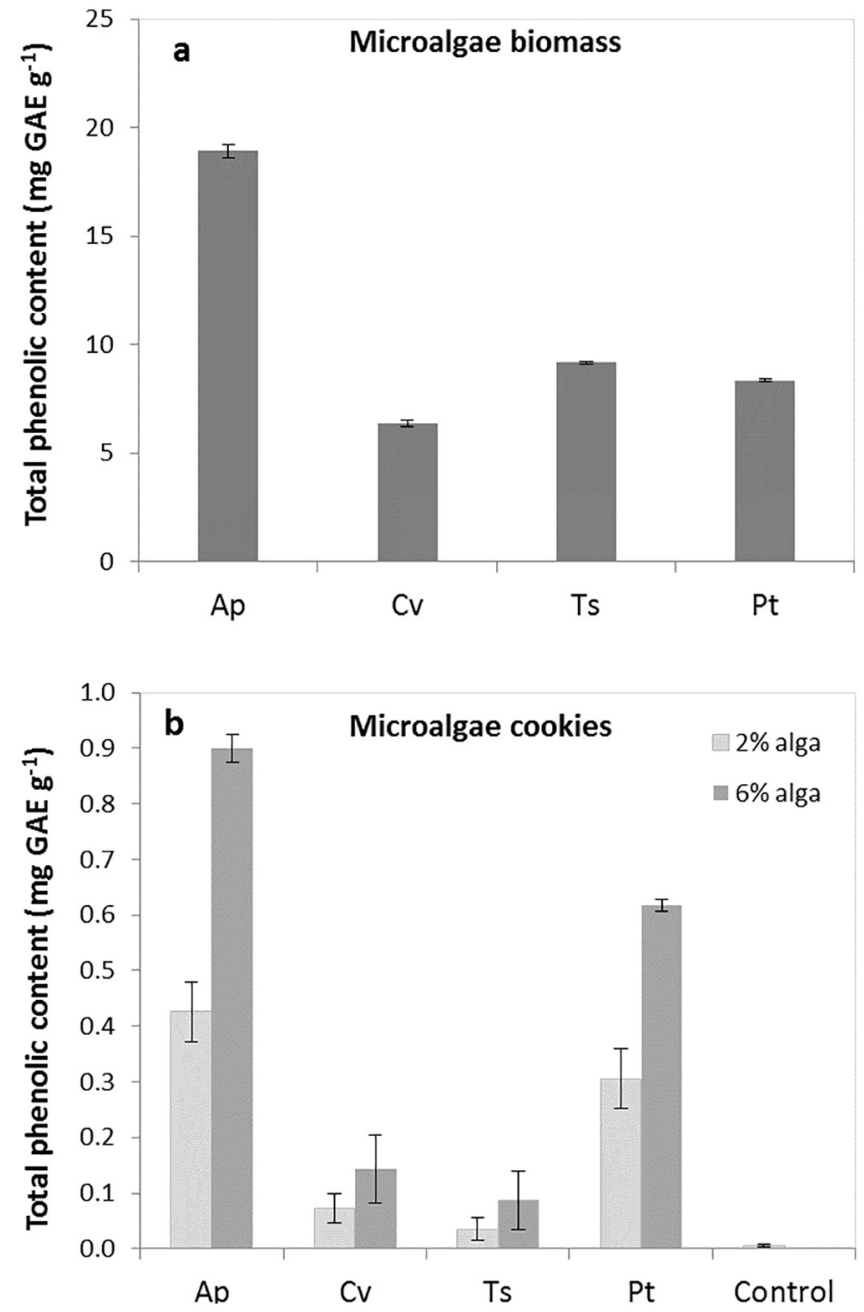

Fig. 5. Total phenolic content (expressed as gallic acid equivalents $\mathrm{mg} \mathrm{g}^{-1}$ dry weight) of four microalgae strains (a) and in cookies enriched with different levels of microalgae (b) (Ap - A. platensis, $\mathrm{Cv}-$ C. vulgaris, Ts - T. suecica, $\mathrm{Pt}-$ P. tricornutum). Results are expressed as average \pm standard deviation $(\mathrm{n}=3)$.

phenolics from thermal degradation. Therefore, P. tricornutum could become an interesting functional ingredient for future developments.

Other authors have highlighted the high phenolic compounds content of A. platensis [55], and P. tricornutum [56], as well as the correlation with the antioxidant activity of these algae extracts. Bolanho et al. [49] report $12 \mathrm{mg} \mathrm{GAE} \mathrm{g}^{-1}$ total phenolics for A. platensis biomass (in the present work: $19 \mathrm{mg} \mathrm{GAE}^{-1}$ ) and, for $5 \%$ A. platensis cookies, an increase from 1.4 to $2.3 \mathrm{mg} \mathrm{GAE}^{-1}$ in total phenolic content when compared to the control, which is in the same order of magnitude than that found in our study for $6 \% \mathrm{~A}$. platensis cookies (from 0.01 to $0.90 \mathrm{mg} \mathrm{GAE}^{-1}$ ). Tumbas Saponjac et al. [15] studied sour cherry pomace extract incorporation in cookies and obtained $0.8 \mathrm{mg} \mathrm{GAE} \mathrm{g}^{-1}$ total polyphenols, a value close to $6 \% \mathrm{~A}$. platensis cookies in the present work.

The antioxidant capacity of microalgae-enriched cookies and biomass was tested by the FRAP method (Fig. 6a and b).

$P$. tricornutum biomass presented the highest $(p<0.05)$ antioxidant capacity $\left(248 \mathrm{mmol}\right.$ TEAC $\left.\mathrm{kg}^{-1}\right)$, followed by $C$. vulgaris (193 mmol TEAC $\mathrm{kg}^{-1}$ ), and by A. platensis and T. suecica (about $160 \mathrm{mmol} \mathrm{TEAC} \mathrm{kg}{ }^{-1}$ ) (Fig. 6A). In addition to phenolic content, $P$. tricornutum has a high content of the carotenoid fucoxanthin, which is a valuable pigment with several biological activities, such as antioxidant activity [25-26]. Compared to other microalgae, green microalgae such as Chlorella and Tetraselmis have antioxidant activity thanks to the high content of chlorophylls ( $a$ and $b$ ) [57] and vitamin E [58], which

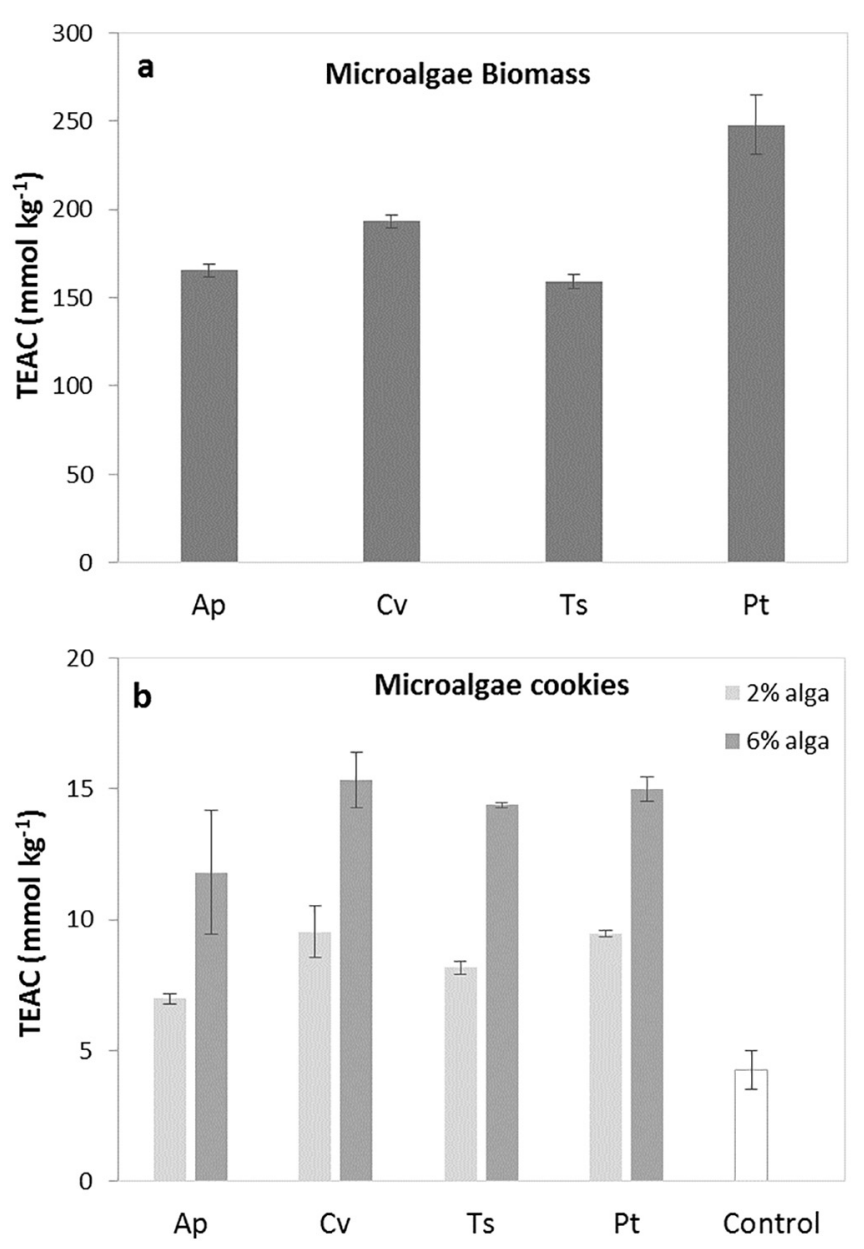

Fig. 6. Antioxidant capacity (expressed as mmol of Trolox Equivalent Antioxidant Capacity, TEAC, per kg) of four microalgae strains (a) and in cookies enriched with different levels of microalgae (b) (Ap - A. platensis, Cv - C. vulgaris, Ts $-T$. suecica, $\mathrm{Pt}-P$. tricornutum). Results are expressed as average \pm standard deviation $(\mathrm{n}=3)$.

includes compounds with antioxidant activity [59], such as tocopherols (up to $125 \mu \mathrm{g} \mathrm{g}^{-1} \mathrm{dw}$ in T. suecica F \& M-M33 [58] and tocotrienols [59]. As reported by Lanfer-Marquez et al. [60], chlorophylls are capable of inhibiting the DPPH radical. A study conducted by Siriwardhana et al. [61] also reported a high correlation between DPPH radical scavenging activities and total polyphenolic content.

Compared to the control cookie, the incorporation of microalgae led to a significant $(p<0.05)$ increase in the antioxidant capacity of all the microalgae-based cookies (even at the lowest dosage). For all the cookies it was observed a significant increase in antioxidant capacity when increasing biomass concentration from 2 to $6 \%$, although at the same biomass concentration, no significant differences $(p<0.05)$ in antioxidant capacity were found between the four tested microalgae cookies. Overall, cookies with $2 \%$ alga showed values from 7.0 to 9.5 mmol TEAC kg ${ }^{-1}(+65 \%$ and $+125 \%$ compared the control cookie, respectively) while $6 \%$ cookies showed values from 11.8 to 15.4 mmol TEAC kg-1 $(+178 \%$ and $+262 \%$ compared the control cookie, respectively).

In the case of $P$. tricornutum, there seems to be a greater loss of microalgae antioxidants upon baking. The important reduction of the antioxidant activity observed in the $P$. tricornutum cookies (compared to the value in biomass, Fig. 6A) could be attributed to the loss of pigments upon baking, in particular the degradation of fucoxanthin, an unstable molecule sensitive to light, oxygen, and high temperature [62]. In fact, it was also noticed color loss of this sample upon cooking (Table 3).

Some other authors have studied the antioxidant capacity of $A$. 
platensis enriched cookies. El Baky et al. [11] and Singh et al. [12] attributed the antioxidant activity of $A$. platensis enriched-cookies to the phycobiliproteins provided by this cyanobacterium. El Baky et al. [11] observed increasing antioxidant activity for biscuits containing 0.3 to $0.9 \%$ A. platensis biomass. Singh et al. [12] found a linear positive correlation between A. platensis concentration (1.6 to 8.4\%) in sorghum flour biscuits, and antioxidant activity. Our results are in agreement with the findings of El Baky et al. [11] and Singh et al. [12] considering that after baking A. platensis cookies (both 2 and 6\%) still showed a high content of phycocyanin, supposedly responsible for the observed antioxidant activity.

\subsection{In vitro digestibility}

The in vitro digestibility analysis reproduces the chemical-enzymatic catalysis that occurs in the proximal tract of the monogastric digestive system [42]. As far as digestibility of algae is concerned, most of the literature deals with tests for macroalgae [63-65] and only few studies focus on the digestibility of microalgae [66-68]. To our knowledge, no literature is available concerning in vitro digestibility of microalgaebased cookies.

The in vitro digestibility (IVD) results are presented in Fig. 7. T. suecica and $P$. tricornutum microalgae biomass presented the lowest IVD (around 50\%). The differences among the microalgae tested could be related to their different cell wall structure [69-71]. No significant difference in IVD between microalgae cookies and the control (IVD 87-95\%) were found.
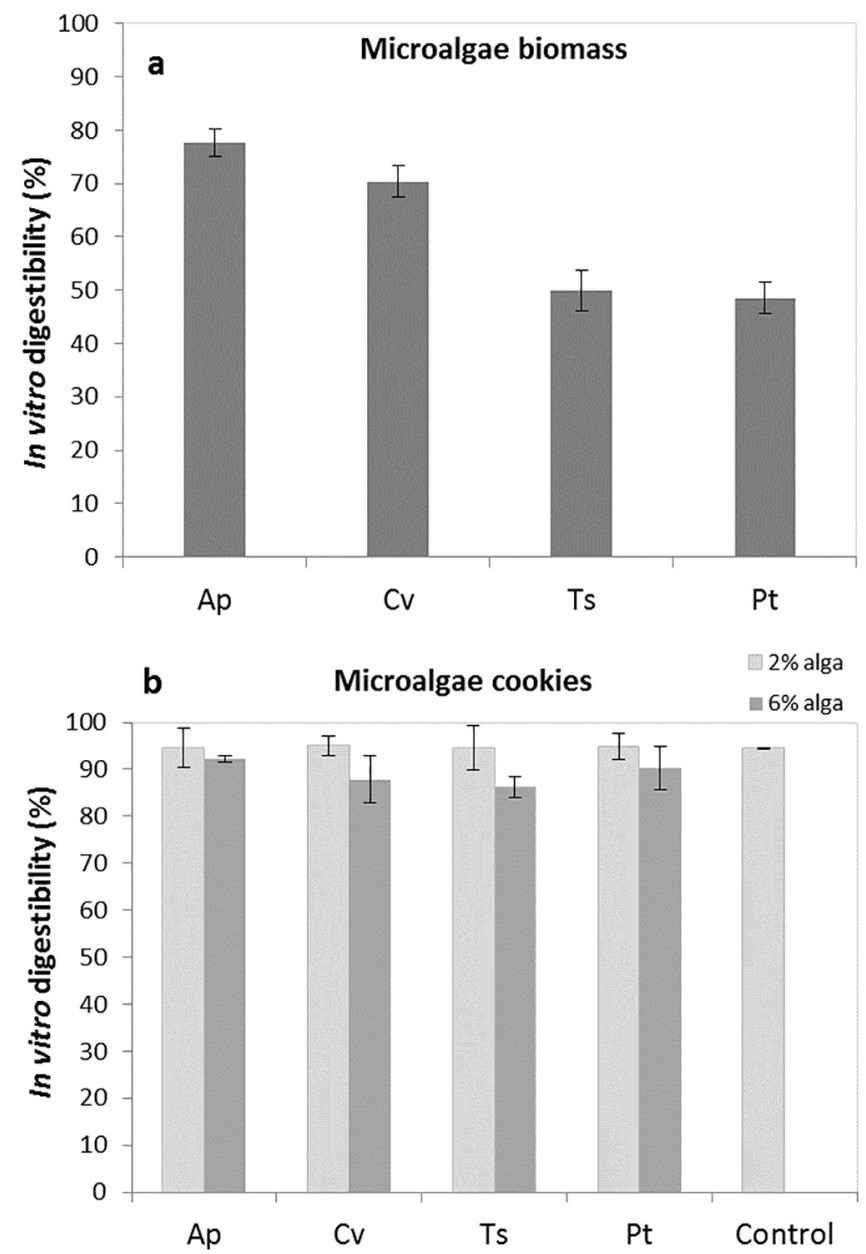

Fig. 7. In vitro digestibility (\%) of four microalgae strains (a) and in cookies enriched with different levels of microalgae (b) (Ap - A. platensis, Cv - C. vulgaris, Ts - T. suecica, $\mathrm{Pt}-P$. tricornutum). Results are expressed as average \pm standard deviation $(n=3)$.

\subsection{Sensory evaluation}

At the end of this work, sensory analysis assays were carried out with $A$. platensis and C. vulgaris microalgae cookies, at $2 \%$ and $6 \%$ incorporation level. These species are already widely accepted as food, then they are more present in the food market compared to other microalgae. Moreover, in restricted tasting sessions by the research team, it was observed that $T$. suecica and $P$. tricornutum marine algae had a very intense fishy flavor, so they were less appreciated.

Fig. 8 represents the average scores of the sensorial parameters as evaluated by the panel. It is clear that the less appreciated sample was $6 \%$ C. vulgaris. Regarding color, the preferred cookie was $2 \%$ C. vulgaris while in terms of smell the tasters preferred the cookies with A. platensis. Concerning texture there were no significant differences between A. platensis ( $2 \%$ and $6 \%$ ) and C. vulgaris $2 \%$, while C. vulgaris $6 \%$ was the less appreciated. In relation to taste and global appreciation, the preferred cookie was A. platensis $2 \%$, while $6 \%$ A. platensis and $2 \%$ C. vulgaris had similar scores. From Fig. 8 it can also be observed that the average of the analyzed sensorial attributes reached (at maximum) the scale 4, corresponding to "pleasant".

As found by many authors, the results of sensory analyses of microalgae-based products such as pasta [9-10,72], cookies [11-12,49] or yoghurt [73] reveal that these products are generally appreciated. Similar to our results, El Baky et al. [11] reported that functional biscuits supplemented with different levels of Spirulina platensis biomass $(0.3$, 0.6 and $0.9 \%$ incorporation level), were significantly acceptable for sensory parameters (color, odor/aroma, flavor, texture), global appreciation, and overall acceptability. Singh et al. [12] reported that biscuits prepared from sorghum and whole wheat flour with the addition of Spirulina platensis ( $>7 \%$ incorporation level) adversely affected the textural and sensory attributes of flavor and graininess. Bolanho et al. [49] also found the addition of S. platensis biomass (2 and 5\%) in the cookies decreased the sensorial acceptance when compared to the control cookie.

Fig. 9 presents the answers given by the tasters in relation to the buying intention. Forty six percent of the tasters "would probably buy" and $22 \%$ "would certainly buy" the cookie with $2 \%$ A. platensis, the most appreciated cookie. Also $39 \%$ and $37 \%$ of the tasters "would probably buy" the $6 \%$ A. platensis and $2 \%$ C. vulgaris cookies, respectively. The $6 \%$ C. vulgaris cookie was clearly unappreciated with $39 \%$ of the tasters referring that "certainly wouldn't buy" and 34\% "probably wouldn't buy".

In the comments field, in the sensory analysis sheet, the $2 \% A$. platensis cookie was considered the crunchiest, tastier and most equilibrated in terms of flavor. Regarding the cookie with $6 \%$ A. platensis the tasters referred that the color was too dark, but that it was very pleasant in terms of taste. The $2 \%$ C. vulgaris cookie, was referred as the one with most appealing color, although it presented a strange residual taste. In relation to the $6 \%$ C. vulgaris cookie the tasters referred that it had a very strong fishy flavor, which lasted in the after-taste feeling.

\section{Conclusions}

The addition of microalgae biomass as natural ingredient resulted in cookies with an attractive and innovative appearance. Innovative and stable green tonalities varied, depending on the microalga used, from a blueish-green (A. platensis) to a brownish-green ( $P$. tricornutum). A. platensis provided a significant structuring effect, in terms of cookies texture. In general, increasing microalgae content from $2 \%$ to $6 \%$ resulted in a significant $(p<0.05)$ increase in the cookies total phenolic content and antioxidant capacity, while concerning digestibility no significant differences compared to the control cookie were found. A. platensis cookies presented the highest sensory scores, as well as high protein and phenolic content. This study suggests that microalgae-based cookies could become widely appreciated and consumed functional foods in the next future. 


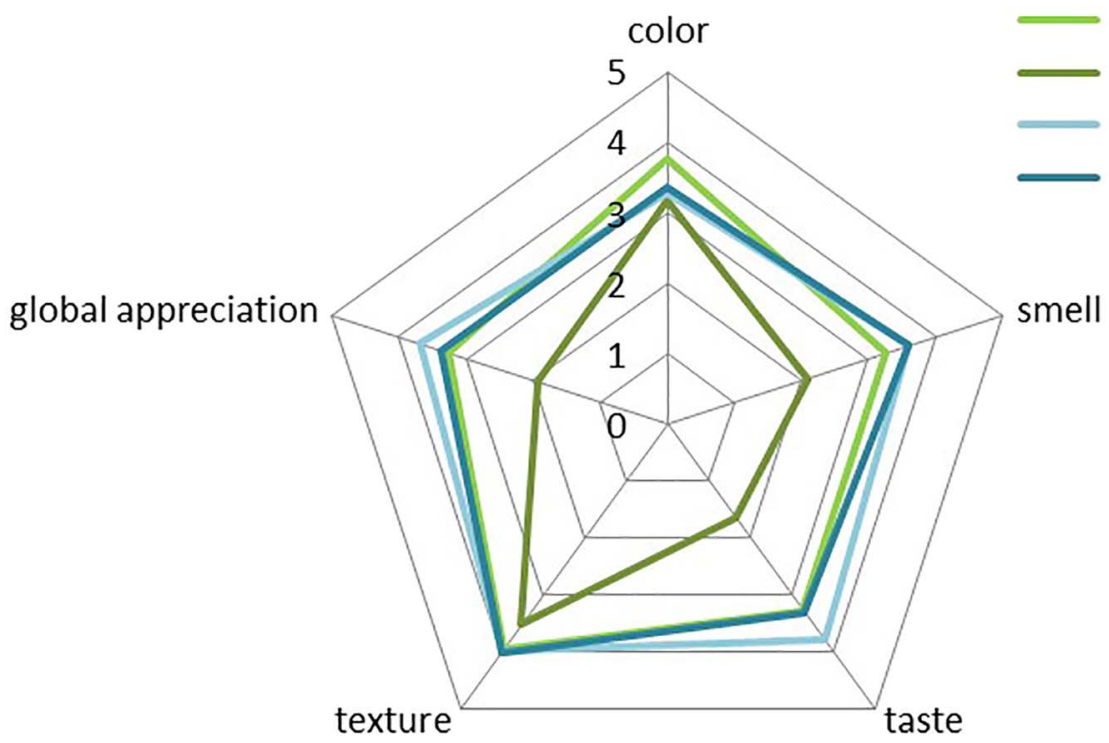

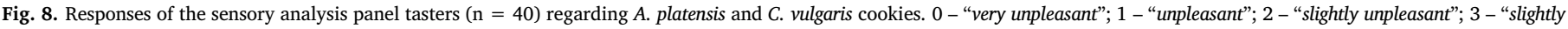
pleasant"; 4 - "pleasant"; 5 - "very pleasant".

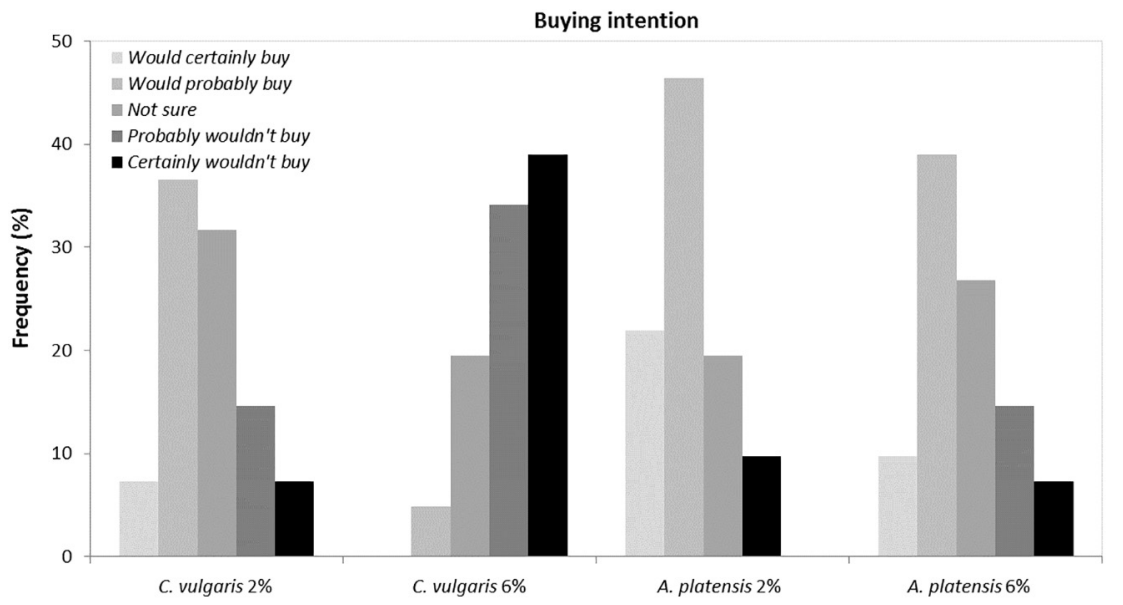

Fig. 9. Responses of the sensory analysis panel tasters $(n=40)$ regarding A. platensis and $C$. vulgaris cookies intention of buying.

\section{Acknowledgments}

This work was supported by national funds from Fundação para a Ciência e a Tecnologia (Portugal) through the research unit UID/AGR/ 04129/2013 (LEAF) and by COST Action ES1408 EUALGAE (European Network for Algal Bioproducts). The authors wish to thank Dr. Graziella Chini Zittelli from the Institute of Ecosystem Study of the CNR in Sesto Fiorentino (Italy) for the use of laboratories, Archimede Ricerche S.r.l. (Italy) and Allma (Portugal) for providing some of the biomasses used in this work. Patricia Fradinho acknowledges $\mathrm{PhD}$ grant from Universidade de Lisboa and Ivana Bursic acknowledges Erasmus grant.

\section{Conflict of interest}

A. platensis F\& M-C256, Tetraselmis suecica F\& M-M33, and Phaeodactylum tricornutum F \& M-M40 belong to the Microalgae Culture Collection of Fotosintetica \& Microbiologica S.r.l., in which M.R. Tredici and L. Rodolfi have a financial interest; all the other authors have no conflicts of interest.

\section{References}

[1] M. Plaza, M. Herrero, A. Cifuentes, E. Ibanez, Innovative natural functional ingredients from microalgae, J. Agric. Food Chem. 57 (2009) 7159-7170, http://dx. doi.org/10.1021/jf901070g.
[2] L. Alemany-Costa, Creation of a new Food Matrix of Bakery Products with Chlorella vulgaris, 7th Food Technology International Symposium. Murcia, Spain, (2015) (http://www.ctnc.es/recursos/publico/PonenciasVIISymposium/05-\%20Laia $\% 20$ Alemany.pdf ).

[3] L. Alemany-Costa, Selection and application of a strain of Chlorella vulgaris in an industry of pastries and bakery products, Book of Abstracts of 2nd EABA and EC Algae Contractors' Conference and the 9th International Algae Congress. P.181. Lisbon, Portugal, 2015.

[4] Credence Research, Algae Products Market by Application (Nutraceuticals, Food \& Feed Supplements, Pharmaceuticals, Paints \& Colorants, Pollution Control, Others) - Growth, Future Prospects, Competitive Analysis, and Forecast 2016-2023, (2016) (http://www.credenceresearch.com/report/algae-products-market ).

[5] C. Enzing, M. Ploeg, M. Barbosa, L. Sijtsma, Microalgae-based products for the food and feed sector: an outlook for Europe, in: M. Vigani, C. Parisi, E. Rodríguez-Cerezo (Eds.), JRC Scientific and Policy Reports, European Commission, 2014, , http://dx. doi.org/10.2791/3339.

[6] A.P. Batista, M.C. Nunes, P. Fradinho, L. Gouveia, I. Sousa, A. Raymundo, J.M. Franco, Novel foods with microalgal ingredients - effect of gel setting conditions on the linear viscoelasticity of Spirulina and Haematococcus gels, J. Food Eng. 110 (2012) 182-189, http://dx.doi.org/10.1016/j.jfoodeng.2011.05.044.

[7] L. Gouveia, A.P. Batista, A. Miranda, J. Empis, A. Raymundo, Chlorella vulgaris biomass used as coloring source in traditional butter cookies, Innovative Food Sci. Emerg. Technol. 8 (2007) 433-436, http://dx.doi.org/10.1016/j.ifset.2007.03.026.

[8] L. Gouveia, C. Coutinho, E. Mendonça, A.P. Batista, I. Sousa, N.M. Bandarra, A. Raymundo, Functional biscuits with PUFA- $\omega 3$ from Isochrysis galbana, J. Sci. Food Agric. 88 (2008) 891-896, http://dx.doi.org/10.1002/jsfa.3166.

[9] M. Fradique, A.P. Batista, M.C. Nunes, L. Gouveia, N.M. Bandarra, A. Raymundo, Chlorella vulgaris and Spirulina maxima biomass incorporation in pasta products, J. Sci. Food Agric. 90 (2010) 1656-1664, http://dx.doi.org/10.1002/jsfa.3999.

[10] M. Fradique, A.P. Batista, M.C. Nunes, L. Gouveia, N.M. Bandarra, A. Raymundo, Isochrysis galbana and Diacronema vlkianum biomass incorporation in pasta products as PUFA's source, LWT Food Sci. Technol. 50 (2013) 312-319, http://dx.doi.org/ 
10.1016/j.lwt.2012.05.006.

[11] H.H.A. El-Baky, G.S. El-Baroty, E.A. Ibrahem, Functional characters evaluation of biscuits sublimated with pure phycocyanin isolated from Spirulina and Spirulina biomass, Nutr. Hosp. 32 (2015) 231-241, http://dx.doi.org/10.3305/nh.2015.32.1. 8804.

[12] P. Singh, R. Singh, A. Jha, P. Rasane, A.K. Gautam, Optimization of a process for high fibre and high protein biscuit, J. Food Sci. Technol. 52 (2015) 1394-1403, http://dx.doi.org/10.1007/s13197-013-1139-z.

[13] M.F.J. Raposo, R.M.S.C. Morais, A.M.M.B. Morais, Health applications of bioactive compounds from marine microalgae, Life Sci. 93 (2013) 479-486, http://dx.doi. org $/ 10.1016 /$ j.lfs.2013.08.002

[14] E.R. De Marco, M.E. Steffolani, C.S. Martínez, A.E. León, Effects of Spirulina biomass on the technological and nutritional quality of bread wheat pasta, LWT Food Sci. Technol. 58 (2014) 102-108, http://dx.doi.org/10.1016/j.lwt.2014.02.054.

[15] V.T. Tumbas Saponjak, G. Cetkovic, J. Canadanovic-Brunet, B. Pajin, S. Djilas, J. Petrovic, I. Loncarevic, S. Stajcic, S. Vulic, Sour cherry pomace extract encapsulated in whey and soy proteins: incorporation in cookies, Food Chem. 207 (2016) 27-33, http://dx.doi.org/10.1016/j.foodchem.2016.03.082.

[16] P. Fradinho, M.C. Nunes, A. Raymundo, Developing consumer acceptable biscuits enriched with psyllium fibre, J. Food Sci. Technol. 52 (2015) 4830-4840, http://dx. doi.org/10.1007/s13197-014-1549-6.

[17] G. Abdulqader, L. Barsanti, M.R. Tredici, Harvest of Arthrospira platensis from Lake Kossorom (Chad) and its household usage among the Kanembu, J. Appl. Phycol. 12 (2000) 493-498, http://dx.doi.org/10.1023/A:1008177925799.

[18] Regulation (EC) $n^{\circ} 258 / 97$ of the European Parliament and of the Council of 27 January 1997 concerning novel foods and novel food ingredients. Official Journal of the European Union, L 43/1 of 14 February 1997, pp. 1.

[19] Regulation (EU) $n^{\circ} 2015 / 2283$ of the European Parliament and of the Council of 25 November 2015 on novel foods, amending Regulation (EU) $n^{\circ} 1169 / 2011$ of the European Parliament and of the Council and repealing Regulation (EC) $n^{\circ} 258 / 97$ of the European Parliament and of the Council and Commission Regulation (EC) $n^{\circ}$ 1852/2001. Official Journal of the European Union, L 327/1 of 11 December 2015, p. 1.

[20] A. Hongsthong, B. Bunnag, Overview of Spirulina: biotechnological, biochemical and molecular biological aspects, in: P.M. Gault, H.J. Marler (Eds.), Handbook on Cyanobacteria: Biochemistry, Biotechnology and Applications, Nova Science Publishers, 2009, pp. 51-103.

[21] E. Reyes-Suárez, S.M. Bugden, F.B. Kai, J.A. Kralovec, M.D. Noseda, C.J. Barrow, T.B. Grindley, First isolation and structural determination of cyclic $\beta$ - $(1 \rightarrow 2)$-glucans from an alga, Chlorella pyrenoidosa, Carbohydr. Res. 343 (2008) 2623-2633, http://dx.doi.org/10.1016/j.carres.2008.07.009.

[22] M. Tabarsa, I.S. Shin, J.H. Lee, U. Surayot, W.J. Park, S.G. You, An immune-enhancing water-soluble $\alpha$-glucan from Chlorella vulgaris and structural characteristics, Food Sci. Biotechnol. 24 (2015) 1933-1941, http://dx.doi.org/10.1007/ s10068-015-0255-0.

[23] European Commision, https://ec.europa.eu/food/sites/food/files/safety/docs/ novel-food_authorisation_2014_auth-letter_tetraselmis_chuii_en.pdf, (2014).

[24] P. Pérez-López, S. González-García, R.G. Ulloa, J. Sineiro, G. Feijoo, M.T. Moreira, Life cycle assessment of the production of bioactive compounds from Tetraselmis suecica at pilot scale, J. Clean. Prod. 64 (2014) 323-331, http://dx.doi.org/10. 1016/j.jclepro.2013.07.028.

[25] B. Gilbert-López, A. Barranco, M. Herrero, A. Cifuentes, E. Ibáñez, Development of new green processes for the recovery of bioactives from Phaeodactylum tricornutum, Food Res. Int. (2016), http://dx.doi.org/10.1016/j.foodres.2016.04.022 (in press).

[26] K. Mikami, M. Hosokawa, Biosynthetic pathway and health benefits of fucoxanthin, an algae-specific xanthophyll in brown seaweeds, Int. J. Mol. Sci. 14 (2013) 13763-13781, http://dx.doi.org/10.3390/ijms140713763.

[27] A. Niccolai, E. Bigagli, N. Biondi, L. Rodolfi, L. Cinci, C. Luceri, M.R. Tredici, In vitro toxicity of microalgal and cyanobacterial strains of interest as food source, J. Appl. Phycol. 29 (2017) 199-209, http://dx.doi.org/10.1007/s10811-016-0924-2.

[28] G. Chini Zittelli, N. Biondi, L. Rodolfi, M.R. Tredici, Photobioreactors for mass production of microalgae, in: A. Richmond, Q. Hu (Eds.), Handbook of Microalgal Culture: Applied Phycology and Biotechnology, 2nd edition, Wiley, Oxford, UK, 2013, pp. 225-266, , http://dx.doi.org/10.1002/9781118567166.ch13.

[29] M.R. Tredici, N. Bassi, M. Prussi, N. Biondi, L. Rodolfi, G.C. Zittelli, G. Sampietro, Energy balance of algal biomass production in a 1-ha "Green Wall Panel" plant: how to produce algal biomass in a closed reactor achieving a high net energy ratio, Appl. Energy 154 (2015) 1103-1111, http://dx.doi.org/10.1016/j.apenergy.2015.01. 086.

[30] M.R. Tredici, L. Rodolfi, N. Biondi, N. Bassi, G. Sampietro, Techno-economic analysis of microalgal biomass production in a 1-ha Green Wall Panel (GWP ${ }^{\circledR}$ ) plant, Algal Res. 19 (2016) 253-263, http://dx.doi.org/10.1016/j.algal.2016.09.005.

[31] R.R.L. Guillard, J.H. Ryther, Studies of marine planktonic diatoms. I. Cyclotella nana Hustedt and Detonula confervacea Cleve, Can. J. Microbiol. 8 (1962) 229-239, http://dx.doi.org/10.1139/m62-029.

[32] C. Zarrouk, Contribution à l'étude d'une cyanophycée. Influence de divers facteurs physiques et chimiques sur la croissance et la photosynthèse de Spirulina maxima (Setch et Gardner) Geitler, Université de Paris, France, 1966 (PhD Thesis).

[33] F. Abiusi, G. Sampietro, G. Marturano, N. Biondi, L. Rodolfi, M. D'Ottavio, M.R. Tredici, Growth, photosynthetic efficiency, and biochemical composition of Tetraselmis suecica F \& M-M33 grown with LEDs of different colors, Biotechnol. Bioeng. 111 (2014) 956-964, http://dx.doi.org/10.1002/bit.25014.

[34] A.O.A.C, Method 950.36 - protein in bread, Official Methods of Analysis, $18^{\text {th }}$ edition, Association of the Official Analytical Chemists, 2006.

[35] NP 4168, Cereais e derivados - determinação do teor de matéria gorda total, Instituto Português da Qualidade, Lisboa, 1991.
[36] S. Boussiba, A.E. Richmond, Isolation and characterization of phycocyanins from the blue-green alga Spirulina platensis, Arch. Microbiol. 120 (1979) 155-159, http:// dx.doi.org/10.1007/BF00409102.

[37] A. Reis, A. Mendes, H. Lobo-Fernandes, J.A. Empis, J. Maggiolly Novais, Production, extraction and purification of phycobiliproteins from Nostoc sp, Bioresour. Technol. 66 (1998) 181-187, http://dx.doi.org/10.1016/S09608524(98)00064-9.

[38] M. Hajimahmoodi, M.A. Faramarzi, N. Mohammadi, N. Soltani, M.R. Oveisi, N. Nafissi-Varcheh, Evaluation of antioxidant properties and total phenolic contents of some strains of microalgae, J. Appl. Phycol. 22 (2010) 43-50, http://dx.doi.org/ 10.1007/s10811-009-9424-y.

[39] G. Rajauria, A.K. Jaiswal, N. Abu-Ghannam, S. Gupta, Antimicrobial, antioxidant and free radical-scavenging capacity of brown seaweed Himanthalia elongata from western coast of Ireland, J. Food Biochem. 37 (2013) 322-335, http://dx.doi.org/ 10.1111/j.1745-4514.2012.00663.x.

[40] A. Serpen, V. Gokmen, N. Pellegrini, V. Fogliano, Direct measurement of the total antioxidant capacity of cereal products, J. Cereal Sci. 48 (2008) 816-820, http://dx. doi.org/10.1016/j.talanta.2013.02.061.

[41] A. Serpen, V. Gokmen, V. Fogliano, Solvent effects on total antioxidant capacity of foods measured by direct QUENCHER procedure, J. Food Compos. Anal. 26 (2012) 52-57, http://dx.doi.org/10.1016/j.jfca.2012.02.005.

[42] S. Boisen, J.A. Fernández, Prediction of the total tract digestibility of energy in feedstuffs and pig diets by in vitro analyses, Anim. Feed Sci. Technol. 68 (1997) 277-286, http://dx.doi.org/10.1016/S0377-8401(97)00058-8.

[43] ISO, EN ISO 8589. Sensory Analysis; General Guidance for the Design of Test Rooms, (2010).

[44] A.P. Batista, L. Gouveia, N.M. Bandarra, J.M. Franco, A. Raymundo, Comparison of microalgal biomass profiles as novel functional ingredient for food products, Algal Res. 2 (2013) 164-173, http://dx.doi.org/10.1016/j.algal.2013.01.004.

[45] M.R. Castellar, J.M. Obón, J.A. Fernández-López, The isolation and properties of a concentrated red-purple betacyanin food colorant from Opuntia stricta fruits, J. Sci. Food Agric. 86 (2006) 122-128, http://dx.doi.org/10.1002/jsfa.2285.

[46] S.P. Fragoso, Desenvolvimento de bolachas com incorporação de diferentes microalgas, Instituto Superior de Agronomia. Universidade de Lisboa, Portugal, 2016 (Master Thesis).

[47] B.P. Carter, M.T. Galloway, G.S. Campbell, A.H. Carter, The critical water activity from dynamic dewpoint isotherms as an indicator of crispness in low moisture cookies, J. Food Meas. Charact. 9 (2015) 463-470, http://dx.doi.org/10.1007/ s11694-015-9254-3.

[48] M. Karel, Lipid oxidation, secondary reactions, and water activity of foods, in: M.G. Simic, M. Karel (Eds.), Autoxidation in Food and Biological Systems, Springer Science, 1980, pp. 191-206, , http://dx.doi.org/10.1007/978-1-4757-9351-2 12.

[49] B.C. Bolanho, M.B. Egea, A.L.M. Jácome, I. Campos, J.C.M. Carvalho, E.D.G. Danesia, Antioxidant and nutritional potential of cookies enriched with Spirulina platensis and sources of fibre, J. Food Nutr. Res. 53 (2014) 171-179.

[50] B. Fernández-Rojas, B. Hernández-Juárez, J. Pedraza-Chaverri, Nutraceutical properties of phycocyanin, J. Funct. Foods 11 (2014) 375-392, http://dx.doi.org/ 10.1016/j.jff.2014.10.

[51] A.P. Batista, A. Raymundo, I. Sousa, J. Empis, J.M. Franco, Colored food emulsions - implications of pigment addition on the rheological behavior and microstructure, Food Biophys. 1 (2006) 216-227, http://dx.doi.org/10.1007/s11483-006-9022-3.

[52] H.H.A. El-Baki, F.K. El Baz, G.S. El-Baroty, Production of phenolic compounds from Spirulina maxima microalgae and its protective effects, Afr. J. Biotechnol. 8 (2009) 7059-7067.

[53] L. Machu, L. Misurcova, J.V. Ambrozova, J. Orsavova, J. Mlcek, J. Sochor, T. Jurikova, Phenolic content and antioxidant capacity in algal food products, Molecules 20 (2015) 1118-1133, http://dx.doi.org/10.3390/molecules20011118.

[54] B. Tesson, C. Gaillard, V. Martin-Jézéquel, Insights into the polymorphism of the diatom Phaeodactylum tricornutum Bohlin, Bot. Mar. 52 (2009) 104-116, http://dx doi.org/10.1515/BOT.2009.012.

[55] R.A. Kepekçi, S.D. Saygideger, Enhancement of phenolic compound production in Spirulina platensis by two-step batch mode cultivation, J. Appl. Phycol. 24 (2012) 897-905.

[56] J.M. Santana-Casiano, M. González-Dávila, A.G. González, M. Rico, A. López, A. Martel, Characterization of phenolic exudates from Phaeodactylum tricornutum and their effects on the chemistry of Fe(II)-Fe(III), Mar. Chem. 158 (2014) 10-16, http://dx.doi.org/10.1007/s10811-011-9710-3.

[57] E. Wang, M. Wink, Chlorophyll enhances oxidative stress tolerance in Caenorhabditis elegans and extends its lifespan, PeerJ 4 (2016) e1879, , http://dx. doi.org/10.7717/peerj.1879.

[58] G. Chini Zittelli, L. Rodolfi, N. Biondi, M.R. Tredici, Productivity and photosynthetic efficiency of outdoor cultures of Tetraselmis suecica in annular columns, Aquaculture 216 (2006) 932-943, http://dx.doi.org/10.1016/j.aquaculture.2006.08.011.

[59] M.G. Traber, J. Atkinson, Vitamin E, antioxidant and nothing more, Free Radic. Biol. Med. 43 (2007) 4-15, http://dx.doi.org/10.1016/j.freeradbiomed.2007.03. 024.

[60] U.M. Lanfer-Marquez, R.M. Barros, P. Sinnecker, Antioxidant activity of chlorophylls and their derivatives, Food Res. Int. 38 (2005) 885-891.

[61] N. Siriwardhana, K.W. Lee, S.H. Kim, J.W. Ha, Y.J. Jeon, Antioxidant activity of Hizikia fusiformis on reactive oxygen species scavenging and lipid peroxidation in hibition, Food Sci. Technol. Int. 9 (2003) 339-346.

[62] S.M. Kim, Y.J. Jung, O.N. Kwon, K.H. Cha, B.H. Um, D. Chung, C.H. Pan, A potential commercial source of fucoxanthin extracted from the microalga Phaeodactylum tricornutum, Appl. Biochem. Biotechnol. 166 (2012) 1843-1855, http://dx.doi.org/ 10.1007/s12010-012-9602-2.

[63] J. Fleurence, Seaweed proteins: biochemical, nutritional aspects and potential uses, 
Trends Food Sci. Technol. 10 (1999) 25-28, http://dx.doi.org/10.1016/S09242244(99)00015-1.

[64] L. Paiva, E. Lima, A.I. Neto, J. Baptista, A multienzyme methodology for in vitro digestibility estimation of protein concentrates from Azorean macroalgae and its amino acid profiles, Planta Med. 80 (2014) P1N30, , http://dx.doi.org/10.1055/s0034-1394620.

[65] S.M. Tibbets, J.E. Milley, S.P. Lall, Nutritional quality of some wild and cultivated seaweeds: nutrient composition, total phenolic content and in vitro digestibility, J. Appl. Phycol. 28 (2016) 3575-3585, http://dx.doi.org/10.1007/s10811-0160863-y.

[66] L. Mišurcovà, S. Kráčmar, K. Bořivoj, J. Vacek, Nitrogen content, dietary fiber, and digestibility in algal food products, Czech J. Food Sci. 28 (2010) 27-35.

[67] L. Machů, L. Mišurcová, D. Samek, J. Hrabě, M. Fišera, In vitro digestibility of different commercial edible algae products, J. Aquat. Food Prod. Technol. 23 (2014) 423-435, http://dx.doi.org/10.1080/10498850.2012.721873.

[68] S.M. Tibbetts, T. MacPherson, P.J. McGinn, A.H. Fredeen, In vitro digestion of microalgal biomass from freshwater species isolated in Alberta, Canada for monogastric and ruminant animal feed applications, Algal Res. 19 (2016) 324-332, http://dx.doi.org/10.1016/j.algal.2016.01.016.

[69] R.A. Andersen, The microalgal cell, in: A. Richmond, Q. Hu (Eds.), Handbook of Microalgal Culture: Applied Phycology and Biotechnology, $2^{\text {nd }}$ edition, Wiley, Oxford, UK, 2013, pp. 3-20, , http://dx.doi.org/10.1002/9781118567166.ch1.

[70] L. Mišurcová, Seaweed digestibility and methods used for digestibility determination, in: S.K. Kim (Ed.), Handbook of Marine Macroalgae: Biotechnology and Applied Phycology, John Wiley and Sons Ltd., 2011, pp. 285-301, , http://dx.doi. org/10.1002/9781119977087.ch13.

[71] L. Tomaselli, Morphology, ultrastructure and taxonomy of Arthrospira (Spirulina) maxima and Arthrospira (Spirulina) platensis, in: A. Vonshak (Ed.), Spirulina platensis (Arthrospira): Physiology, Cell-Biology and Biotechnology, Taylor and Francis, 1997, pp. 1-19.

[72] N. Zouari, M. Abid, N. Fakhfakh, M.A. Ayadi, L. Zorgui, M. Ayadi, H. Attia, Bluegreen algae (Arthrospira platensis) as an ingredient in pasta: free radical scavenging activity, sensory and cooking characteristics evaluation, Int. J. Food Sci. Nutr. 62 (2011) 811-813, http://dx.doi.org/10.3109/09637486.2011.582461.

[73] R.P. Dubey, P. Kumari, Preparation of low fat and high protein frozen yoghurt enriched with papaya pulp and Spirulina, Trends Biosci. 4 (2011) 182-184. 